\title{
Millijoules per Square Centimeter
}

National Cancer Institute

\section{Source}

National Cancer Institute. Millijoules per Square Centimeter. NCI Thesaurus. Code

C116241.

A unit of radiant exposure defined as a unit of energy equal to one millijoule applied to a unit of area equal to one square centimeter. 